\title{
Retreatment of Chronic Hepatitis B e Antigen-Positive Patients With Recombinant Interferon Alfa-2a
}

\author{
Vicente Carreño, ${ }^{1}$ Patrick Marcellin, ${ }^{2}$ Stephanos Hadziyannis, ${ }^{3}$ Javier Salmerón, ${ }^{4}$ Moisés Diago,${ }^{5}$ Geoge E. Kitis, ${ }^{6}$ \\ Irene Vafiadis, ${ }^{7}$ Solko W. Schalm, ${ }^{8}$ Friederike Zahm, ${ }^{9}$ Félix Manzarbeitia, ${ }^{10}$ F. Javier Jiménez, ${ }^{11}$ Juan Antonio Quiroga, ${ }^{1}$ \\ and the European Concerted Action on Viral Hepatitis (EURohep)
}

Fifty-seven patients with chronic hepatitis B, hepatitis B virus (HBV) e antigen (HBeAg) and HBV DNA positivity, and aminotransferase el evation despite a previous course of any type of adequate interferon alfa (IF $\mathrm{N}-\alpha$ ) therapy were included in a multicenter prospective randomized controlled trial. The objective of the study was to compare a second course of IFN- $\alpha$ therapy ( 9 million units [MU] of IF $-\alpha-2 a$, Roferon-A, thrice weekly for 6 months) versus no therapy in terms of loss of HBV DNA and HBeAg. At the end of the study, a sustained clearance of HBV DNA and HBeAg was observed in 9 of the $27(33.3 \%)$ patients who had received retreatment with IFN $-\alpha$ compared with $3 / 30(10 \%)$ patients who spontaneously cleared these markers in the untreated control group $\left(\chi^{2}=4.66, P=.031\right.$; odds ratio: 4.5, 95\%; confidence interval: 1.1-18.9). None of the responders lost HBsAg. Patients retreated with IFN- $\alpha$ were more likely to have biochemical remission in association with HBV clearance $(5 / 27,18.5 \%)$ compared with untreated patients (1/30, 3.3\%; Fisher's exact test $P=.09$ ). Histological improvement in the liver necroinflammatory activity was observed among sustained responders to IFN $-\alpha$ retreatment, consisting of regression of the portal and periportal inflammation and of the piecemeal necrosis; there was no change in the degree of liver fibrosis. Side effects were similar to those previously reported during IF $-\alpha$ treatment; these were mild and reversible on IF $\mathrm{N}-\alpha$ discontinuation. None of the baseline features were associated with response by Cox's regression analysis. In summary, viremic patients with chronic HBeAg-positive hepatitis may experi-

Abbreviations: $H B V$, hepatitis $B$ virus; $H B e A g$, hepatitis B virus e antigen; $A L T$, alanine transaminase; $\mathrm{HBsAg}$, hepatitis $B$ virus surface antigen; IF $-\alpha$, interferon alfa.

From the ${ }^{1}$ Department of Hepatology, Fundación Jiménez Díaz, Madrid, Spain; the 2Service d'Hépatologie, Hôpital Beaujon, Clichy, France; the ${ }^{3}$ Department of Internal Medicine II, Hippokration General Hospital, Athens, Greece; the ${ }^{4}$ Department of Digestive Diseases, Hospital Clínico Universitario, Granada, Spain; the ${ }^{5}$ Department of Digestive Diseases, Hospital General Universitario, Valencia, Spain; the ${ }^{6}$ Department of Gastroenterology, George Papanicolau General Hospital, Thessaloniki, Greece; the 'Laiko General Hospital, Athens, Greece; the ${ }^{8}$ Department of Internal Medicine II, University Hospital Dijkzigt, Rotterdam, The N etherlands; the ${ }^{9} \mathrm{~F}$. Hoffmann-La Roche, Basel, Switzerland; and the Departments of ${ }^{10}$ Pathology and ${ }^{11}$ Epidemiology and Biostatistics, Fundación Jiménez Díaz, Madrid, Spain.

Received December 18, 1998; accepted April 9, 1999.

This study was supported by a grant from F. Hoffmann-La Roche, Basel, Switzerland and by a grant from the European Community.

Address reprint requests to: Vicente Carreño, M.D., Department of Hepatology, Fundación Jiménez Díaz, Avda. Reyes Católicos, 2, 28040 Madrid, Spain. E-mail: vcarreno@uni.fjd.es; fax (+34) 91544-9228.

Copyright $\odot 1999$ by the American Association for the Study of Liver Diseases.

0270-9139/99/3001-0037\$3.00/0 ence disease remission following retreatment with IFN- $\alpha$. Thus, retreatment with IF $\mathrm{N}-\alpha$ may be considered a therapeutic option. (Hepatology 1999;29:277-282.)

It has been proven that chronic hepatitis B virus (HBV) infection may have a progressive course ending in liver cirrhosis or hepatocellular carcinoma. ${ }^{1,2}$ Interferon alfa (IFN- $\alpha$ ) has been used as therapy for this disease, leading to a sustained loss of HBV DNA and hepatitis B e antigen ( $\mathrm{HBeAg}$ ) (and seroconversion to anti-HBe) and biochemical improvement (normalization of alanine transaminase [ALT] values) in around $25 \%$ to $40 \%$ of the treated patients. ${ }^{2-10}$ However, the remaining patients do not achieve a response, including those patients who relapse after achieving an initial response and patients who do not respond. These patients may potentially benefit from another cycle of IF N- $\alpha$ treatment.

Attempts in pilot studies of retreatment with IFN- $\alpha$ for previous nonresponders provided no definite conclusions on its possible efficacy in chronic HBV. ${ }^{11}$ No controlled trial evaluating the benefits of retreatment of chronic HBV with IFN - $\alpha$ has been published. The objective of our study has been to determine whether a second course of IF $\mathrm{N}-\alpha$, given during 6 months, is safe and acceptable, and whether it results in a significantly higher treatment response (loss of HBeAg and HBV DNA) than no treatment in previously nonresponder patients with chronic HBV.

\section{PATIENTS AND METHODS}

Study Design. This study was designed as a multicenter (see Appendix) randomized controlled trial in patients who failed to respond to a previous cycle of IFN- $\alpha$. Assuming that patients with no treatment show a $5 \%$ response, and patients with retreatment $25 \%$ (a $20 \%$ difference), ${ }^{7}$ a total number of 145 patients was needed to detect a significant difference at the $5 \%$ level with a power of $80 \%$, taking into account a possible $25 \%$ drop-out rate during the study. The inclusion period started in April 1992 and ended in December 1996. At that time, 62 patients who were HBeAg- and HBV DNA-positive in serum with abnormal ALT values (documented at least 3 times within the 6 months screening period) and a chronic HBV $^{12}$ documented in a liver biopsy obtained within 1 year before inclusion had been enrolled. The patients should have undergone a previous treatment of only one course of any type of IFN- $\alpha$ treatment (recombinant or lymphoblastoid) for at least 12 weeks with a minimum of 13.5 million units ( $M U$ ) per week ${ }^{8,13}$; at the end of the first IFN - $\alpha$ cycle ( at least 6 months before enrollment in this study) patients should have been $\mathrm{HBeAg}$-positive.

The following patient exclusion criteria were used: (1) evidence of any other type of liver disease, i.e., anti-hepatitis $C$ virus or anti-hepatitis D virus positive, alcohol, ascites, bleeding varices, or 
hepatic encephalopathy; (2) immunocompromised patient (antiHIV-positive, transplantation, hemodialysis, etc.); (3) active intravenous drug use or presence of significant medical illness that might interfere with this trial; (4) women with positive pregnancy test or not practicing an adequate birth control method; (5) patients with neuropsychiatric disorders including seizures; (6) low levels of hemoglobin $(<6 \mathrm{mmol} / \mathrm{L})$, white blood cell $\left(<3 \times 10^{9} / \mathrm{L}\right)$ or platelet ( $\left.<70 \times 10^{9} / \mathrm{L}\right)$ counts; $(7)$ class B or C cirrhosis according to the Child Pugh classification; and (8) previous treatment other than IFN - $\alpha$ in the preceding 12 months.

The dose and treatment duration were selected because better results are obtained with doses of 4.5 to 18 MU 3 times per week during 12 to 24 weeks $6,8,14$ and with prolongation of the treatment period. ${ }^{13} \mathrm{~F}$ or these reasons, a 6 -month treatment course was chosen with a dose of $9 \mathrm{MU}$ of recombinant IFN (rIFN)- $\alpha$-2a (Roferon-A, F. Hoffmann-La Roche, Basel, Switzerland), subcutaneously, 3 times per week. Eligible patients were randomized to treatment or observation. Patients in the control group were observed for the same period, and both groups were studied further for another 6-month period after completing treatment or observation. This study was approved by the Eurohep and local Ethics Committees and conducted in accordance with the guidelines of "Good Clinical Practice," which underwrites the principles of the declaration of Helsinki on human experimentation. Written informed consent according to local legal requirements was obtained from each patient participating in this study.

Laboratory Tests. HBsAg, HBeAg, anti-HBe, and anti-hepatitis D virus were determined by commercial assays (Abbott Labs., N orth Chicago, IL); anti-hepatitis C virus was tested by EIA (Ortho). Biochemical and hematological parameters were measured by standard methods; a liver ultrasound was also performed. During and after therapy, the patients (treated and untreated) were examined at every visit. Blood was drawn every month and locally analyzed for HBeAg, ALT, leukocytes, and platelets. Aliquots of serum samples were stored at $-20^{\circ} \mathrm{C}$ and shipped frozen for central examination of the virus load in one center (Madrid, Spain). HBV DNA was quantitated by a liquid hybridization assay (Abbott) with a detection limit of $1.7 \mathrm{pg} / \mathrm{mL} .{ }^{15}$ For statistical analysis, the detection limit was assigned to samples with undetectable levels.

Efficacy and Safety Criteria. Response was defined as the loss of serum HBV DNA and HBeAg at the end of treatment (6 months). At the end of follow-up (12 months), those patients with a persisting response according to the above criteria were defined as sustained responders whereas those patients who lose any or all response criteria were considered as relapsers; patients who did not achieve the response criteria were considered nonresponders. A second liver biopsy was obtained in 34 patients who agreed to undergo this procedure one year after the start of treatment or the no-treatment period. Changes in liver histology between the baseline and follow-up biopsies were reviewed for each individual patient centrally and blindly by the same pathologist. Safety assessments were done according to the World Health Organization classification of toxicity. Paracetamol (up to $4 \times 500 \mathrm{mg}$ ) was given to minimize side-effects of IFN $-\alpha$. Patients were withdrawn from the analysis of intention-totreat wherever the eligibility criteria had not been complied with, thus influencing the evaluation of efficacy. All patients who received test medication and had at least one postbaseline assessment were included in the safety analysis.

Statistical Analysis. The similarity of clinical and laboratory characteristics of the 2 groups at randomization was assessed using the $\chi^{2}$ and Mann-Whitney's tests. All the data were analyzed on an intention-to-treat basis. The kinetics of HBV DNA concentrations were studied by Wilcoxon's signed rank test or M ann-W hitney's test in paired or independent samples, respectively. The Kaplan-M eier analysis was performed to assess the difference in the occurrence of $\mathrm{HBV}$ DNA and $\mathrm{HBeAg}$ clearance between IFN- $\alpha$ retreatment and no treatment. The time of these events was estimated at the midpoint between the last positive value and the first negative value. The association of baseline features with treatment response was evalu- ated by Cox's regression analysis to estimate relative risks as odds ratios and confidence intervals. All P-values reported are two-tailed. Statistical analysis was performed using the SPSS program (v7.5) (SPSS Inc., Chicago, IL).

\section{RESULTS}

Of the 62 patients randomized, 5 were excluded ( 3 in the retreatment and 2 in the untreated control group, respectively) because of protocol violation that potentially could bias the study (e.g., negative HBV DNA in 4, normal ALT values in 1). Thus, 57 patients started the protocol, 27 in the IF N- $\alpha-2$ a retreatment group, and 30 in the untreated control group. There were no differences in the baseline demographics between study groups (Table 1).

During IFN- $\alpha$ retreatment, serum HBV DNA levels decreased with respect to the basal values, and the difference was significant compared with the control group at the end of therapy ( $P=.029)$. Also, at the end of the follow-up period, the serum HBV DNA concentration was significantly lower than the basal sample in treated patients $(P<.01)$ but not in controls (Fig. 1). At the end of retreatment, or the observation period for untreated controls, there was a greater, although not statistically significant, disappearance of HBV DNA in the retreated patients (7/27, 26\%) compared with the controls $(3 / 30,10 \%)$. Serum HBV DNA re-appeared in 2 retreated patients but became negative in 7, as well as in 7 untreated controls. Thus, HBV DNA clearance was higher, but not significantly, in the retreated patients (12/27, 44\%) compared with the untreated controls (10/30, 33\%) at the end of the study.

Loss of HBeAg was greater in the retreatment group at the end of therapy $(6 / 27,22 \%)$ compared with the control group $(3 / 30,10 \%)$, although the difference was not statistically significant. However, at the end of the follow-up, loss of $\mathrm{HBeAg}$ was significantly more frequent in the treated patients $(11 / 27,41 \%)$ than in the untreated controls $(5 / 30,17 \%)$ $\left(x^{2}=4.08, P=.043\right)$.

TABLE 1. Baseline Demographics of the Patients in Groups as Established by Randomization

\begin{tabular}{|c|c|c|c|}
\hline & $\begin{array}{l}\text { IFN- } \alpha \text { Retreatment } \\
(\mathrm{n}=27)\end{array}$ & $\begin{array}{l}\text { Untreated Control } \\
\qquad(\mathrm{n}=30)\end{array}$ & $\mathbf{P}$ \\
\hline Age $(y r)^{*}$ & $31(18-63)$ & $33(18-61)$ & 0.64 \\
\hline Gender (M/F) & $26 / 1$ & $25 / 5$ & 0.11 \\
\hline $\begin{array}{l}\text { Duration of HBsAg positivity } \\
\text { (mo } *\end{array}$ & & & 0.81 \\
\hline ALT $\dagger$ & & & 0.54 \\
\hline HBV DNA in serum $(\mathrm{pg} / \mathrm{mL})^{*}$ & $82.0(1.72-636)$ & $50.7(2.28-920)$ & 0.37 \\
\hline $\begin{array}{l}\text { Liver histology (chronic hepati- } \\
\text { tis): minimal/mild/moder- } \\
\text { ate/NA }\end{array}$ & $8 / 13 / 1 / 5$ & $8 / 17 / 2 / 3$ & 0.75 \\
\hline Liver cirrhosis: no. (\%) & $3(11)$ & $2(7)$ & 0.90 \\
\hline $\begin{array}{l}\text { Previous IFN (total dose in } \\
\text { MU)* }\end{array}$ & $600(180-1080)$ & $696(234-2592)$ & 0.40 \\
\hline $\begin{array}{l}\text { No. (\%) given }<432 \text { MU IFN } \\
\text { No. rIFN- } \alpha-2 a / r I F N-\alpha-2 b / I F N- \\
\alpha-n 1\end{array}$ & $6(22)$ & $10(33)$ & 0.35 \\
\hline
\end{tabular}

Abbreviations: NA, not available or inadequate for evaluation.

* Results are expressed as median (range) and compared by $x^{2}$ or Mann-Whitney tests.

†M edian (range) of the ratio of ALT values with respect to the upper limit of normal range values.

$\ddagger$ Corresponds to at least $9 \mathrm{MU}$ thrice weekly for 16 weeks. 


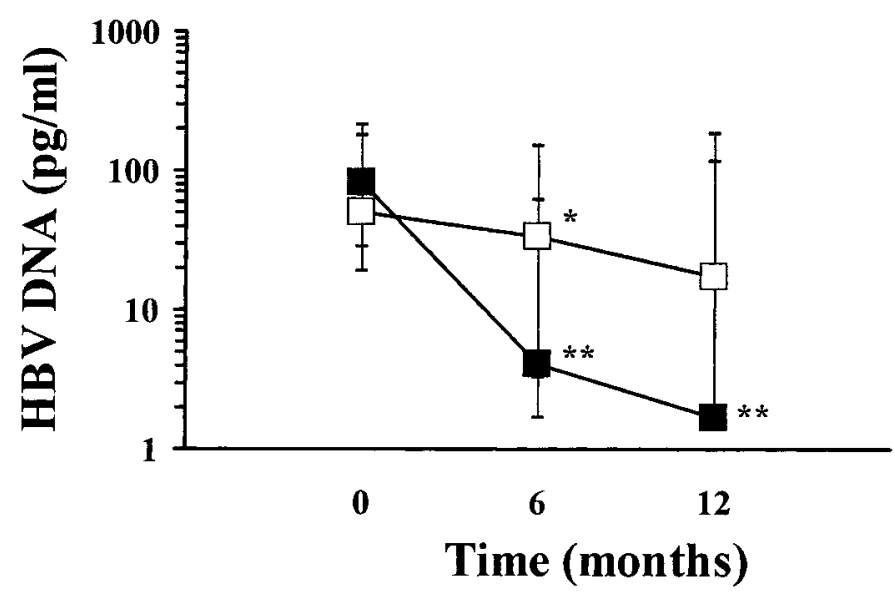

FIG. 1. Serum HBV DNA levels (expressed as the median and the 25th through 75 th percentile) throughout the study in the retreatment $(\boldsymbol{\square})$ and control ( $\square$ ) groups: at the start, at therapy cessation, or the 6-month observation period and at the end of follow-up (12 months). ${ }^{*} \mathrm{P}=.029$ retreatment vs. control. ${ }^{* *} \mathrm{P}<.01$ with respect to the baseline level.

A complete virological response at the end of the study (e.g., sustained clearance of HBV DNA and $\mathrm{HBeAg}$ ) was observed in 9 of the 27 (33\%) patients who had received retreatment with IF $-\alpha$, which was statistically significantly higher compared with $3 / 30$ (10\%) patients who spontaneously cleared these markers in the untreated control group $\left(\chi^{2}=4.66, P=.031\right.$; odds ratio: $4.5,95 \%$; confidence interval: 1.1-18.9). Figure 2 shows the Kaplan-M eier estimate of the combined HBV DNA and HBeAg clearance during the initial 6 months retreatment or observation period in the control group and the 6 months of follow-up. Seroconversion from $\mathrm{HBeAg}$ to anti-HBe was found in 6 of those 9 responders to retreatment (after 6 months in 3 and after 12 months in 3 other patients) and in the 3 untreated controls with spontaneous $\mathrm{HBeAg}$ clearance (after the initial 6 months in 2) (retreatment vs. control: $27 \%$ vs. $10 \%$; P not significant). $\mathrm{N}$ one of the patients lost HBsAg, irrespective of the study group.

Four patients experienced a flare in ALT values ( $>2.5 \times$ baseline ALT value) preceding or at the time of HBV DNA clearance irrespective of the retreatment or control group; the flare ranged from 2.74- to 14.9-fold the baseline value. At the end of the study, ALT levels decreased significantly $(P<.05)$ compared with the baseline in either the sustained responders to retreatment or control patients with HBV clearance. ALT normalization was observed in 6 retreated patients and 5 controls. Of these patients with normal ALT, 5/6 (83\%) were responders to retreatment with IFN- $\alpha$ compared with $1 / 5$ $(20 \%)$ untreated patients (Fisher's exact test $P=.08$; not significant). Thus, retreated patients were more likely to clear HBV and have normal ALT values (5/27, 18.5\%) compared with the untreated controls (1/30,3.3\%) (Fisher's exact test $\mathrm{P}=.09$; not significant ).

Histological scoring was performed in 49 initial liver biopsies (22 in the retreatment and 27 in the untreated control group). No biopsy was available from 7 patients and it was inadequate for evaluation in 1 . There were no significant pretreatment or post-treatment differences in the necroinflammation (Fig. 3) and fibrosis scores among groups. Paired liver biopsies were evaluable in 30 patients (15 in each study group), including $7 / 9$ sustained responders to retreatment, and the 3 untreated controls who cleared HBV spontaneously. A histological improvement in the necroinflammatory activity was observed among sustained responders to IFN- $\alpha$ retreatment as well as in controls with spontaneous HBV

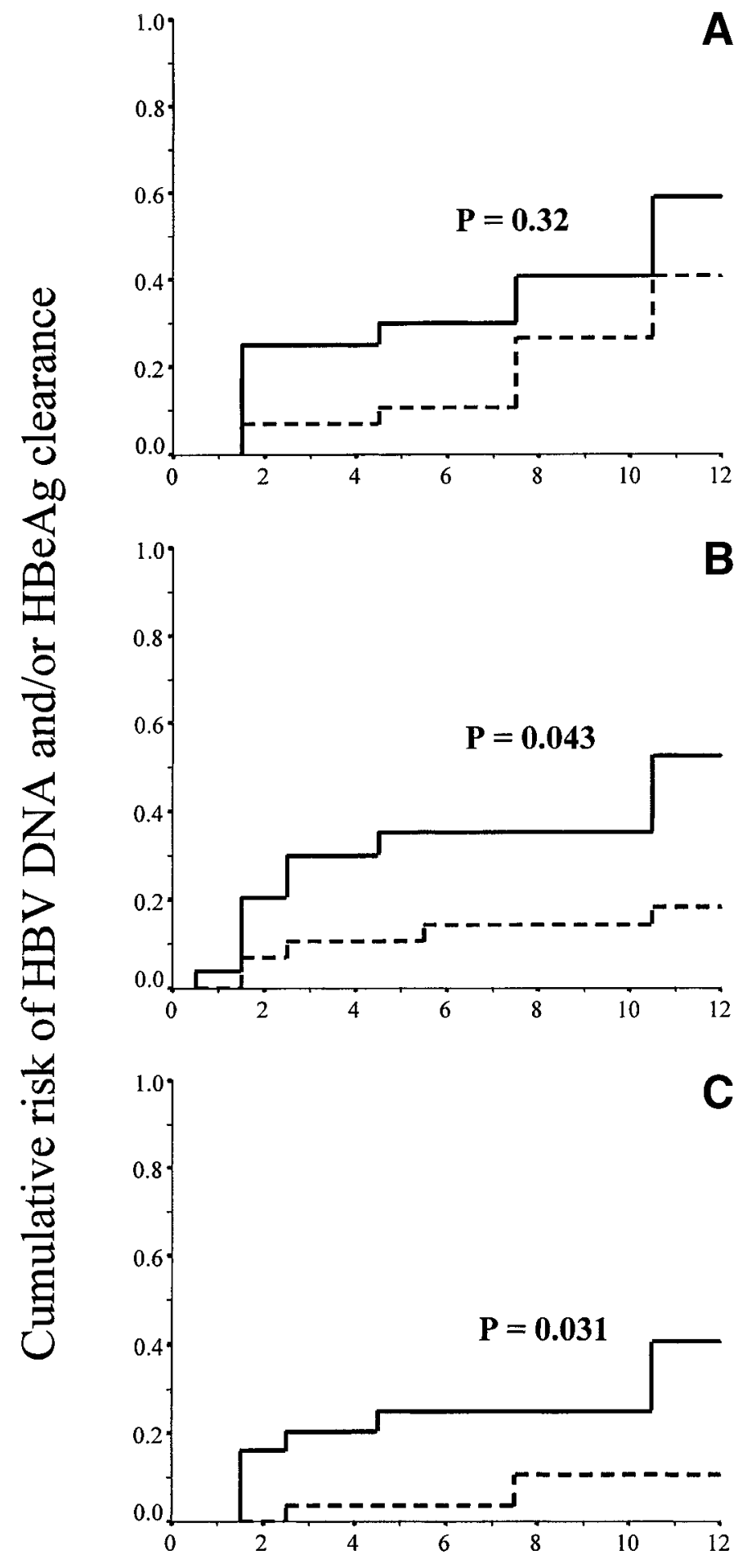

\section{Months after start of therapy}

FIG. 2. Kaplan-M eier estimate of clearance of (A) HBV DNA, (B) HBeAg, and $(C)$ both HBV DNA and HBeAg during the initial 6 months retreatment (solid line) or the observation period in the control group (dashed line) and the 6 months of posterior follow-up. 


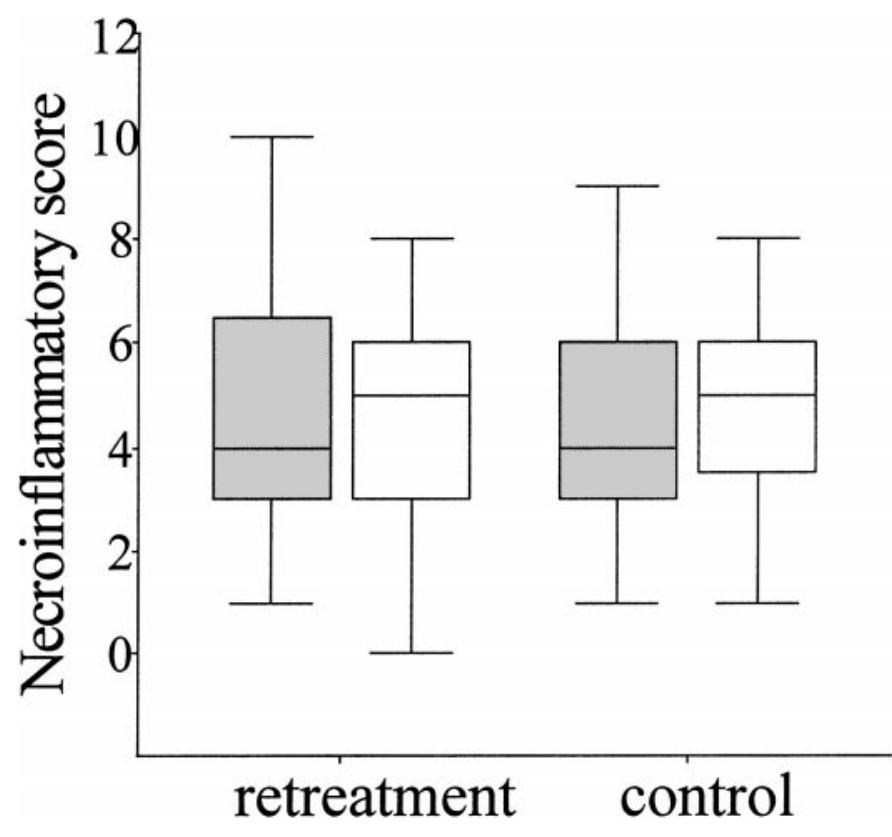

FIG. 3. Box-plot of the liver necroinflammatory score in the retreatment and control groups before therapy ( $\square$ basal) and at the end of the follow-up period ( $\square$ final).

clearance (Table 2). This consisted of regression of the portal and periportal inflammation and of the piecemeal necrosis although the difference was not statistically significant. There was no change in the degree of liver fibrosis. In most of the cases, the necroinflammatory activity worsened in nonresponders. In the final biopsies, the necroinflammatory activity was significantly lower $(P=.012)$ in sustained responders compared with nonresponders (Table 2).

Side effects consisted of a transient flu-like syndrome with fever and myal gia that was seen in most of the patients in the retreatment group during the first IF $-\alpha$ injections. Around $30 \%$ of the patients reported mild to moderate anorexia, fatigue (44\%), and arthralgia (37\%). Other events, such as depression and hair loss were seen in $11 \%$ of the patients; variceal bleeding was not observed in any patient. In all cases the adverse effects attributed to IF $\mathrm{N}-\alpha$ were reversible follow-

TABLE 2. Comparison of the Liver Necroinflammatory Activity (grading) and Fibrosis (staging) in Paired Basal and Final Biopsies in 30 Patients Divided According to the Type of Response*

\begin{tabular}{|c|c|c|c|c|c|}
\hline & \multicolumn{2}{|c|}{$\begin{array}{l}\text { Responders } \\
(\mathrm{n}=10) \dagger\end{array}$} & \multicolumn{2}{|c|}{$\begin{array}{l}\text { Nonresponders } \\
(\mathrm{n}=20) \ddagger\end{array}$} & \multirow[b]{2}{*}{$\mathrm{P} \S$} \\
\hline & Basal & Final & Basal & Final & \\
\hline $\begin{array}{l}\text { Necroinflammatory } \\
\text { activity }\end{array}$ & $4(2-5.5)$ & $3(0.5-5)$ & $4(3-6)$ & $5(4.25-6)$ & 0.012 \\
\hline Portal inflammation & $2(1-2)$ & $1(0.5-2)$ & $2(1.25-3)$ & $2(2-3)$ & 0.001 \\
\hline Piecemeal necrosis & $1(0.5-2)$ & $1(0-1)$ & $1(0.25-2)$ & $1.5(1-2)$ & 0.022 \\
\hline Lobular cytolysis & $1(0-2)$ & $1(0-1.5)$ & $1(0.25-2)$ & $2(1-2)$ & 0.12 \\
\hline Fibrosis & $1(0.5-2.5)$ & $1(0-2.5)$ & $2(1-2)$ & $2(1-3)$ & 0.13 \\
\hline
\end{tabular}

*Results are expressed as median value and the 25th through 75th percentile.

tIncludes $7 / 9$ who were sustained responders to retreatment with IFN - $\alpha$ and the 3 who cleared HBV spontaneously in the control group.

fIncludes 8 nonresponders to retreatment and 12 in the control group.

$\S$ By Mann-Whitney's U sustained responders vs. nonresponders in final biopsies. ing dose modification or cessation of therapy. The corresponding occurrence of these events varied from $3 \%$ to $10 \%$ in the untreated controls. Liver disease decompensation was observed in $1 / 3(33 \%)$ of the retreated cirrhotic patients that required dose-reduction. One noncirrhotic patient required dose-reduction because of abdominal pain. Finally, these 2 patients and another cirrhotic patient who developed hepatocellular carcinoma discontinued retreatment.

In the univariate analysis to assess the predictive factors of response to IF $\mathrm{N}-\alpha$ retreatment, sustained responders tended to be younger, to have higher pretreatment ALT values, and lower HBV DNA concentrations but the differences were not statistically significant (data not shown). Among retreated patients, 6/27 (22\%) had received less than 432 MU total dose of IF $-\alpha$ in the previous cycle; this dose corresponds to at least 9 MU 3 times per week for 16 weeks. Three out of six (50\%) patients having received less than $432 \mathrm{MU}$ total dose of IFN $-\alpha$ in the previous cycle showed a sustained response to IFN $-\alpha$ retreatment compared with $6 / 21(29 \%)$ patients who had received at least $432 \mathrm{MU}$ total dose of IFN- $\alpha$ in the previous cycle ( $P=.37$ by Fisher's exact test). Among the 3 untreated controls who responded, 1/10 (10\%) had received less than, and 2/20 (10\%) equal to or higher than, $432 \mathrm{MU}$ total dose of IFN- $\alpha$ in the previous cycle (P not significant). None of the baseline features were associated with response by Cox's regression analysis (data not shown).

\section{DISCUSSION}

In this randomized controlled trial we have investigated whether retreatment for 6 months with $9 \mathrm{MU}$ of IF N- $\alpha-2 \mathrm{a}$ is efficacious in HBeAg and HBV DNA-positive patients with chronic hepatitis who did not respond to a previous course of appropriate IFN $-\alpha$ treatment. We found that a sustained clearance of these markers occurred significantly more frequently in the retreated patients compared with the unretreated controls (33\% vs. 10\%). In addition, two-thirds of the sustained responders to retreatment had seroconverted to anti-HBe by the end of the 6-month post-treatment followup. Furthermore, 5/9 sustained responders to retreatment had normalized their ALT values, and a regression to normal or near normal histology was observed in 3 of these patients.

A significant response was achieved only at the end of follow-up, but not at the end of the treatment. The reason for this behavior is not clear although there are several possible explanations. Thus, serum HBV DNA concentrations decreased significantly when the basal and end-of-treatment samples are compared. It has been proposed that a high HBV DNA concentration may be associated with inefficient T-cell reactivity against HBV. ${ }^{16,17}$ Thus, a decrease in HBV DNA concentration may help to restore $\mathrm{T}$-cell reactivity against HBV during therapy with clearance of the virus during the post-treatment follow-up. In addition, the possible role of IFN-sensitive/resistant HBV variants in the response to treatment should be taken into consideration. It has been showed that mutant T-cell epitopes of the precore/core region may diminish the antiviral T-cell responses against wild-type HBV. 18 Therefore, during therapy disappearance of T-cell precore/core mutants may help to restore the T-cell responses with subsequent clearance of HBV in the follow-up. However, all these hypotheses require future research.

$\mathrm{N}$ evertheless, the results are encouraging, because in a previous pilot study using 1.5 to $5 \mathrm{MU}$ of IFN- $\alpha$ daily for 16 weeks, the rate of sustained response to retreatment was 
$11 \% .11$ In the present study, the administration of higher doses ( 9 MU, 3 times per week) during 6 months has made it possible to achieve a higher rate of sustained response (33\%). This is specially important because the size of the study population had to be reduced because of the unavailability of the planned number of patients in a reasonable time, even though it was designed as a large European multicenter prospective trial. Thus, only 62 of the planned 145 patients were enrolled. In spite of this, this is the first randomized controlled trial showing the efficacy of the retreatment of chronic hepatitis B with IF $-\alpha$.

None of the sustained responders in the study lost $\mathrm{HBsAg}$ after the first 1-year period. After a single course of IF N- $\alpha$ treatment, the rate of $\mathrm{HBsAg}$ loss during the initial year may vary from $10 \%$ to $22 \%, 5,10,19,20$ M ost HBsAg responses occur several years after $\mathrm{HBeAg}$ and $\mathrm{HBV}$ DNA clearance, ranging from $11.6 \%$ after 5 years to $71 \%$ after 11 years.5,9,10 Whether HBsAg clearance and seroconversion to anti-HBs are delayed in long-term HBV carriers who respond to a second course of treatment is unknown at present, and the clinical significance needs to be re-assessed in the future.

Another important observation in this study is the tolerability of the retreatment, in view of the high dose used and duration, with side effects similar to those already reported during IF N - $\alpha$ treatment. However, liver disease decompensation was observed in 1 of the 3 retreated cirrhotic patients and another developed an hepatocellular carcinoma. The occurrence of decompensation was in accordance with the $28 \%$ reported by Fattovich et al $^{1}$ in tumor-free patients. These issues should be considered when retreating patients with HBV-related cirrhosis.

Finally, we have not identified baseline features that are related to response to retreatment with IFN- $\alpha$ probably because of the small sample size. This is in contrast to the predictive pretreatment factors known to influence the response to IFN - $\alpha$ therapy in IFN -naive patients with chronic hepatitis B. ${ }^{19}$ However, another report based on individual patient data showed that the treatment effect of IF N- $\alpha$ was independent of such variables. ${ }^{21}$ This suggests that some viremic patients with unrecognized clinical and/or virologic characteristics, ${ }^{22}$ who do not respond to initial IFN $-\alpha$ treatment, may benefit from IFN $-\alpha$ retreatment. ${ }^{11}$ Recently, the use of the nucleoside analogs lamivudine ${ }^{23}$ and famciclovir ${ }^{24}$ has been introduced for the treatment of chronic hepatitis $B$ in different settings. ${ }^{2}$ Although lamivudine, the most promising agent, seems to be highly effective in most patients at the start of therapy in naive patients ${ }^{23,25}$ and in previous nonresponders to IF $-\alpha,{ }^{26}$ development of resistance by mutations in the viral polymerase is a significant clinical problem following administration of lamivudine ${ }^{25}$ or famciclovir. ${ }^{27}$ The combination of lamivudine and IF N $\alpha$ does not seem to improve the results of retreatment with IFN- $\alpha$ as recently reported in a pilot study conducted in previous nonresponders to IF N- $\alpha .{ }^{26}$ In conclusion, the results of the present study indicate that retreatment with IFN- $\alpha$ may be considered as a therapeutic option for viremic patients with chronic HBeAg-positive hepatitis.

Acknowledgment: We are indebted to Mabel Ramiro (Madrid) and Stanny de Roode, Marja Bakker, and Ellis Ruijs (Rotterdam) for their assistance in data management and coordination; to Antonio Craxì, Christian Trépo, and Helmer
Ring-Larsen (other members of the Eurohep executive team on antiviral therapy) for their help in the design of the study.

\section{APPENDIX}

The following European centers and investigators have participated in this randomized controlled trial (values in parenthesis denote the number of patients recruited): Spain Fundación Jiménez Díaz, Madrid (12): J.A. Quiroga, M. Pardo, S. Artillo, O. Bosch, and V. Carreńo; Hospital Clínico Universitario, Granada (9): A. Palacios, L. Rodríguez-Ramos, and J. Salmerón; Hospital General Universitario, Valencia (6): R. Zapater and M. Diago. France - Hopital Beaujon, Clichy (11): N. Boyer, P. Marcellin. Greece - Hippokration General Hospital, Athens (9): Ch. Vogiatzi, Ch. Papaioannou, and S. Hadziyannis; General Regional Hospital, Thessaloniki (6): A. Papachristou and G.E. Kitis; Laiko Loimoxeis General Hospital, Athens (5): I. Delladetsima and I. Vafiadis; Ippokratio Hospital, Thessal oniki (1): J. Agorastos. The Netherlands University Hospital Dijkzigt, Rotterdam (3): H.L.A. Janssen and S.W. Schalm.

\section{REFERENCES}

1. Fattovich G, Giustina G, Schalm SW, Hadziyannis S, Sanchez-Tapias J, Almasio $P, C$ hristensen $E$, et al. Occurrence of hepatocellular carcinoma and decompensation in western European patients with cirrhosis type B. HePATOLOGY 1995;21:77-82.

2. Hoofnagle JH, di Bisceglie AM. The treatment of chronic viral hepatitis N Engl J Med 1997;336:347-356.

3. Alexander GJ, Brahm J, Fagan EA, Smith HM, Daniels HM, Eddleston $A L$, Williams R. Loss of HBsAg with interferon therapy in chronic hepatitis B virus infection. Lancet 1987; ii:66-69.

4. Perrillo RP, Schiff ER, Davis GL, Bodenheimer HC Jr, Lindsay K, Payne J, Dienstag $\mathrm{JL}$, et al. A randomized controlled trial of interferon alfa- $2 \mathrm{~b}$ alone and after prednisone withdrawal for the treatment of chronic hepatitis B. N Engl J Med 1990;323:295-301.

5. Carreńo V, Castillo I, Molina J, Porres JC, Bartolome J. Long-term follow-up of hepatitis $B$ chronic carriers who responded to interferon therapy. J Hepatol 1992;15:102-106.

6. Di Bisceglie AM, Fong TL, Fried M W, Swain M G, Baker B, Korenman J, Bergasa NV, et al. A randomized, controlled trial of recombinant alpha-interferon therapy for chronic hepatitis B. Am J Gastroenterol 1993;88:1887-1892.

7. Wong DK, Cheung AM, O'RourkeK, N aylor CD, Detsky AS, Heathcote]. Effect of alpha-interferon treatment in patients with hepatitis $B$ e antigen-positive chronic hepatitis B. A meta-analysis. Ann Intern Med 1993;119:312-323.

8. Thomas HC, Lok ASF, Carreño V, Farrell G, Tanno H, Perez V, Dusheiko $\mathrm{GM}$, et al. Comparative study of three doses of interferon alfa-2a in chronic active hepatitis B. The International Hepatitis Trial Group. J Viral Hepat 1994;1:139-148.

9. Niederau C, Heintges T, Lange S, Goldmann G, Niederau CM, Mohr L, Haussinger D. Long-term follow-up of HBeAg-positive patients treated with interferon alfa for chronic hepatitis B. N Engl J Med 1996;334:14221427.

10. Lau DT, Everhart J, Kleiner DE, Park Y, Vergalla J, Schmid P, Hoofnagle $\mathrm{JH}$. Long-term follow-up of patients with chronic hepatitis B treated with interferon alfa. Gastroenterology 1997;113:1660-1667.

11. Janssen HLA, Schalm SW, Berk L, de Man RA, Heijtink RA. Repeated courses of alpha-interferon for treatment of chronic hepatitis type B. J Hepatol 1993;17(Suppl 3):S47-S51.

12. Desmet VJ, Gerber MA, Hoofnagle JH, Manns M, Scheuer PJ. Classification of chronic hepatitis: diagnosis, grading and staging. HePATOLOGY 1994;19:1513-1520.

13. Janssen HLA, Berk L, Schalm SW, Heijtink RA, Hess G, Rossol S, M eyer zum Buschenfelde $\mathrm{KH}$, et al. Antiviral effect of prolonged intermittent Iymphoblastoid alpha interferon treatment in chronic hepatitis B. Gut 1992;33:1094-1098.

14. Krogsgaard K, Christensen E, Bindslev N, Schalm S, Andersen PK, Ring-Larsen $\mathrm{H}$. Relation between treatment efficacy and cumulative dose 
of al pha interferon in chronic hepatitis B. European Concerted Action on Viral Hepatitis (Eurohep). J Hepatol 1996;25:795-802.

15. Kuhns MC, MCN amara AL, Cabal CM, Decker RH, Thiers V, Brechot $C$, Tiollais P: A new assay for quantitative detection of hepatitis B viral DNA in human serum. In: Zuckerman AJ, ed. Viral hepatitis and liver disease. New York, NY: Alan R. Liss Inc, 1988;258-262.

16. Chisari FV, Ferrari C. Hepatitis B virus immunopathogenesis. Annu Rev Immunol 1995;13:29-60.

17. Bertoletti A, Costanzo A, Chisari FV, Levrero M, Artini M, Sette A, Penna $A$, et al. Cytotoxic T lymphocyte response to a wild type hepatitis $B$ virus epitope in patients chronically infected by variant viruses carrying substitutions within the epitope. J Exp Med 1994;180:933-943.

18. Marinos G, Naoumov NV, Williams R. Impact of complete inhibition of viral replication on the cellular immune response in chronic hepatitis $B$ virus infection. Hepatology 1996;24:991-995.

19. Brook MG, Karayiannis P, Thomas HC. Which patients with chronic hepatitis B virus infection will respond to alpha-interferon therapy? A statistical analysis of predictive factors. HEPATOLOGY 1989;10:761-763.

20. Lok AS, Chung HT, Liu VW, Ma OC. Long-term follow-up of chronic hepatitis B patients treated with interferon alfa. Gastroenterology 1993;105:1833-1838.

21. Krogsgaard K, Bindslev N, Christensen E, Craxi A, Schlichting P, Schalm
$\mathrm{S}$, Carreño $\mathrm{V}$, et al. The treatment effect of alpha interferon in chronic hepatitis B is independent of pre-treatment variables. Results based on individual patient data from 10 clinical controlled trials. J Hepatol 1994;21:646-655.

22. Payne RJH, N owak MA, Blumberg BS. The dynamics of hepatitis B virus infection. Proc Natl Acad Sci U SA 1996;93:6542-6546.

23. Dienstag JL, Perrillo RP, Schiff ER, Bartholomew M, Vicary C, Rubin M. A preliminary trial of lamivudine for chronic hepatitis B infection. $N$ Engl J Med 1995;333:1657-1661.

24. Main J, Brown JL, Howells C, Galassini R, Crossey M, Karayiannis $P$, Georgiou $P$, et al. A double blind, placebo-controlled study to assess the effect of famciclovir on virus replication in patients with chronic hepatitis B virus infection. J Viral Hepat 1996;3:211-215.

25. Jaeckel $E$, Manns MP. Experience with lamivudine against hepatitis $B$ virus. Intervirology 1997;40:322-336.

26. Mutimer D, Naoumov N, Honkoop P, Marinos G, Ahmed M, de Man R, McPhillips $P$, et al. Combination alpha-interferon and lamivudine therapy for alpha-interferon-resistant chronic hepatitis B infection: results of a pilot study. J Hepatol 1998;28:923-929.

27. Bartholomeusz A, Groenen LC, Locarnini SA. Clinical experience with famciclovir against hepatitis B virus. Intervirology 1997;40:337-342. 